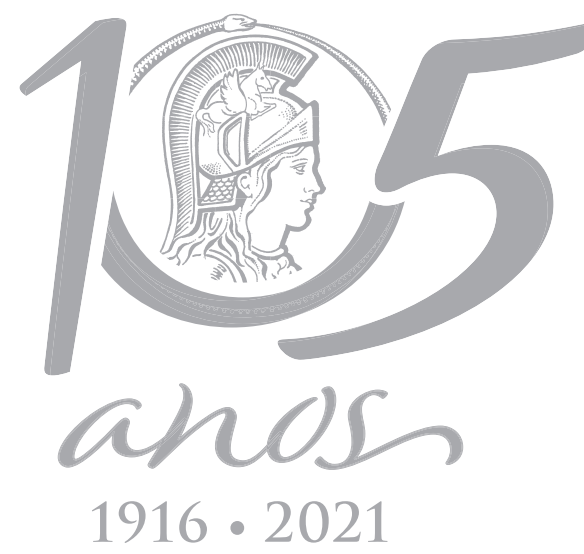

\title{
Cemetery Relocations in Hidroituango: An Interdisciplinary Study
}

\author{
TIMISAY M. VARGAS, CECILIA L. URIBE, SANTIAGO V. BEDOYA, MARY LUZ Q. \\ ZAPATA \& SANTIAGO A. CARDONA-GALLO
}

\begin{abstract}
This study realized the exhumation and transfer of human remains buried in the cemeteries at Orobajo, Barbacoas and La Fortuna (Municipality of Sabanalarga, Peque and Buriticá respectively) within the framework of "Social Management" of the Ituango Hydroelectric Project and the program Integral Restitution of Living Conditions for communities. Methods and techniques from bioanthropology, forensic sciences, archeology and Soil Sciences were used. Cemeteries were characterized by unconventional burials; moreover, documentation of tombs and burial practices were not generalized, nor did they show patterns. In the field assessment, 2,883 pit tests and soil probes using a penetrometer were carried out over a total area of 2,288 square meters. A total of 349 skeletonized human remains were exhumed, almost double of what was expected; of these, 180 were from Orabajo, 151 from Barbacoas, and 18 from La Fortuna. Though the remains showed a great deal of deterioration, age at death was determined for $59 \%$ of cases, and sex identified in $49 \%$. Personal artifacts and clothing items were recovered along with the bones in many cases. Remains from Barbacoas and La Fortuna were given over to communities, and final dispositions were made in sites previously agreed upon (cemeteries in Peque, Buriticá and Sabanalarga respectively).
\end{abstract}

Key words: bioanthropology, archeology, Hidroituango Hydroelectric Project, cemetery transfer.

\section{INTRODUCTION}

The cemetery, or "village of the dead", according to Gennep (1986), is a sociocultural space used for burials (Higgins 2013). In this sense, Pattison (1955) affirmed the literature about ground use, cemeteries have had the tendency of being more deprecated than studied, not only due to the sociocultural significance that frames the fear of death, but also because of public health concerns that ensue after death and the decomposition of the cadaver. Nonetheless, this vision of cemeteries has changed today. When relocated during of large-scale development projects as part of framework that emphasizes cultural recognition, cemeteries can recreate the connection between relocated communities and their ancestors in the new territorial location. The first cemeteries to have value by being relocated in large-scale development projects were historical cemeteries, which were relocated using archeological methodologies including field assessment, localization and excavation (Harris et al. 1970, Ubelaker 1995, Ellis 1996, Harvey 2006, Thiel \& Margolis 2007). Such was the effect of these types of scientific articulations, that Banks \& Czaplicki (2014) published "Dam Projects and the Growth of American Archaeology" about the massive archeological program of data recovery and mitigation during dam construction throughout the 48 contiguous states in the United States. Likewise, Ubelaker 
(1995) established the protocols for localizing, excavating, recuperating, and analyzing skeletonized remains and associated artifacts in cemetery contexts. He even demonstrated the need for protocols to recognize patterns of soil compaction to understand the differences between reference and disturbed soil. consequently, archaeology partnered with bioanthropology to relocate cemeteries and bodies buried within (Ellis 1996, Judd 2004, Banks \& Czaplicki 2014). In the framework of "Social Management" of the Ituango Hydroelectric Project, and under the program Restitución Integral de Condiciones de Vida (Integral Restitution of Living Conditions), subprogram Afectación a la Infraestructura Comunitaria (Effects on Community Infrastructure), Empresas Públicas de Medellín (EPM) carried out a project for the identification, exhumation, and relocation of bodies buried in the cemeteries of Orobajo in the Municipality of Sabanalarga, Barbacoas in the Municipality of Peque, and the sector La Fortuna in the Municipality of Buriticá, all located on the terraces of the Cauca River. These communities were located in the flood zones of the Ituango hydroelectric dam and were relocated to new sites as a consequence of the development project. Social Management is a policy of Empresas Públicas de Medellín (Medellin Public Works) that seeks to act in communities affected by public infrastructure and development projects on communities through incorporating "community participation as a central component" in the production of "information processes, consultation, and coand self-management" (EPM 2013).

Although these were not forensic or archaeological contexts, we relied upon the implementation of mixed methodologies from bioanthropology, forensics, archaeology and edaphology (soil science) to exhume 349 skeletons and ossified remains found throughout the cemeteries at every level of the excavation sites. The project was carried out with intensive collaboration with the local communities, in two periods: pre-fieldwork and fieldwork, each phase requires specific approval and documentation. In the fieldwork period, prior to the initiation of our project, the Fiscalía General de la Nación, Office of the Attorney General, had exhumed the bodies product of violent deaths related to the Colombian Armed Conflict. In the pre-fieldwork phase, the project was proposed to the communities and the protocols for identification, field assessment, rescue and the relocation were designed. Additionally, details for the final disposition of the bodies were agreed upon.

The project was proposed to and discussed with the respective communities in the end of November and beginning of December of 2017. Field assessment with geo-archeological techniques was carried out, tombs were excavated, and skeletonized bodies were exhumed with their associated personal artifacts, from late December 2017 to March 2018. Next, the skeletons and other unassociated bone fragments were cleaned, classified and labelled by the Laboratorio de Osteología Antropológica y Forense (Laboratory of Anthropologic Osteology and Forensics) at the Universidad de Antioquia. Finally, age at death and sex were determined for the skeletal remains. In total, 349 men and women were exhumed. Of these, 180 came from Orobajo in Sabanalarga, 151 from Barbacoas in Peque, and 18 from La Fortuna in Buriticá. The total is almost double the number of bodies expected based on information supplied by the communities (166\% of the expected total). Age at death of the exhumed bodies consisted of all the stages of the life cycle, from prenatal deaths to death in old age. The excavation and exhumation of the bodies was an involved process because cemetery management 
practices were unconventional in the excavation sites and did not meet the standards specified in Colombian cemetery norms (Ministerio de la Protección Social 2010, Resolución 5194). Burial practices were not generalized, nor did they show patterns. All the remains showed high levels of deterioration, possibly due to taphonomic factors like soil pH, tree roots and length of time buried. The remains were also affected by burial practices such as the deposition of some bodies on top of others, or the scattering of skeletons already buried to make room for new burials. At the end of the project, the remains were returned to the communities where they were once again laid to rest in three different religious ceremonies. Ceremonies included symbolic activities in which community members were accompanied by a psychologist specialized in responding to death and grief. The aforementioned ceremonies were held in the municipalities of Peque, Buriticá and Sabanalarga, where the remains from Barbacoas and La Fortuna were reburied. The bodies from Orobajo remain in the custody of the Laboratory of Anthropologic Osteology and Forensics of the Universidad de Antioquia. The final conditions for the reburial of the bodies are still under discussion between EPM and the indigenous community Nutabe at Orobajo as part of the Proceso de Consulta Previa (Previous Consultation Process).

\section{MATERIALS AND METHODS}

\section{Location of the cemeteries}

The exhumed cemeteries are located along the terraces of the Cauca River Basin, a dry tropic forest zone (Bs-T) with an average temperature greater than $24^{\circ} \mathrm{C}$ and an annual rainfall between 1000-2000mm and 380masl (Espinal 1992). The project relocated bodies from the cemeteries at Orobajo, Barbacoas and La Fortuna. See Table
I for geographic coordinates. Figure 1 shows the location of the cemeteries on the map of Antioquia, a department in Colombia.

\section{Materials}

The excavation was carried out following the procedures proposed by Ubelaker (1995). Consequently, the relocation was planned in two periods: pre-fieldwork and fieldwork. During the pre-fieldwork period, research was conducted, protocols were decided upon, methodological design was chosen, and the projects were proposed to the communities for their consideration and approval. The defined protocols included:

1) Proposing the projects to communities for their collaboration and feedback,

2) Photographic record protocol,

3) Field assessment protocol,

4) Excavation protocol,

5) Recovery protocol for ossified remains in the field,

6) Protocol for the treatment of the remains in the laboratory.

The fieldwork period consisted in field assessment, localization, and exhumation (carried out in the field), as well as the preparation and cleaning of ossified material recovered and the determination of sex and age at death (laboratory work). Personnel for the project were updated on the laws and norms currently in force for forensic contexts according to The Minnesota Protocol on the Investigation of Potentially Unlawful Death (2016).

Table I. Geographic coordinates of the cemeteries.

\begin{tabular}{|c|c|c|}
\hline Locality & \multicolumn{2}{|c|}{ Geographic coordinates } \\
\hline Orobajo & $N 7^{\circ} 01.671^{\prime}$ & $W 75^{\circ} 47.536^{\prime}$ \\
\hline Barbacoas & $N 6^{\circ} 55.700^{\prime}$ & $W 75^{\circ} 49.757^{\prime}$ \\
\hline Fortuna & $N 6^{\circ} 46.012^{\prime}$ & $W 75^{\circ} 51.663^{\prime}$ \\
\hline
\end{tabular}


They were also trained in digital photographic documentation based on the regulations used in the investigation of sexual crimes and personal injuries according to the National Institute of Legal Medicine and Forensic Sciences (Medicina Legal 2004) in accordance with the Minimum Forensic Standards for the Search of Disappeared Persons and the Recovery and Identification of Cadavers (Medicina Legal 2017). While the context for these cemetery relocations was not forensic in nature, the project adhered to the fieldwork techniques used by the New York Forensic Office, and additionally conducted a literature review of current methodologies in field assessment and excavation in geo-archeology.

\section{Pre-fieldwork period}

The project was presented to the communities for approval on the $3^{\text {rd }}$ and $4^{\text {th }}$ of December 2017 and the $5^{\text {th }}$ of January of 2018. Once the projects were approved, community members were asked to fill out an antemortem data collection form, produced by the University of Antioquia. This form was used to document and estimate the total number of bodies buried in each of the cemeteries. The instrument consisted of four (4) parts. In the first part, community members were asked to provide the complete name of the deceased, as well the deceased's date of birth and chronological age. The second part established a biological and social profile for the deceased. Information was collected about sex, height, dental and medical history, and pathological injuries, emphasizing traumatic wounds related to bone contexture. Other defining traits such as sports and hobbies and socioeconomic history
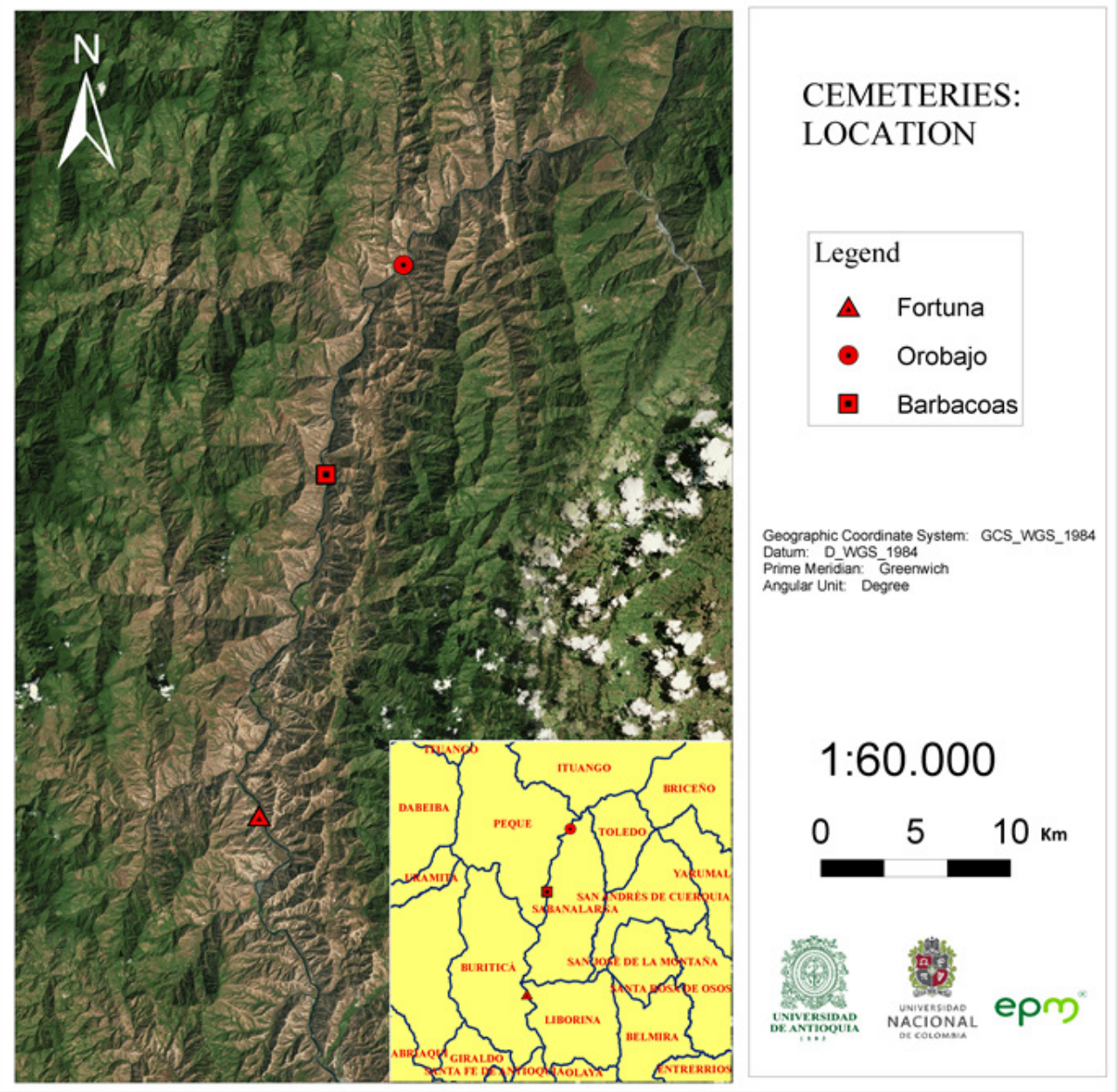

Figure 1. The location of the cemeteries in the map of Antioquia. 
were also identified. Lastly, information about clothing items, accessories, and other objects placed inside the tombs was collected to help in the identification process. In the third part of the firm, burial information and documentation were collected. Finally, in the fourth part, we asked for the community member's information: their full name, their relationship with the deceased and whether they were related on maternal or paternal sides of their family.

\section{Fieldwork period}

\section{Field-assessment phase}

A mixed methodology was used in the fieldassessment phase of the exhumation, utilizing mound and depression recognition from anthropology, as well as pit testing, and soil testing with a penetrometer to locate the tombs. Penetrometer tests of the soil were conducted prior to the removal of vegetation from the surface (see Table II). Initially, the pentrometry techniques were applied outside the limits of the cemetery to find a reference value for the resistance to penetration. The findings were contrasted with the results from the interiors of the cemeteries to establish a pattern of ground compacting and determine the area of antropic intervention. The selected area was marked off with yellow flags. Afterwards, the anthropologist toured the terrain noting the mounds and depressions in the ground surface, which were marked with blue flags as possible burial sites (see Figure 2)

In total, 2,883 probes were realized to determine the limits of the excavation sites (See Table II). Additionally, a few specific burial sites were identified through the information gathered from the inhabitants of the locality. A point with a high probability of corresponding with a tomb was assigned an alphanumeric code with the three first letters of the name of the cemetery and a consecutive identification number. For the photographic documentation of the site before beginning the excavation, a reference arrow was placed at the north end of the site (See Figure 3)

\section{Excavation}

The first part of the excavation was carried out with big tools like shovels, coca shovels, pallets, bars and spades as suggested by Ubelaker (1995). Close to the wooden coffin or the ossified remains, small tools like masonry trowels, gardening shovels, dustpans and buckets were used. The ground above the skeletons was removed with brushes of different sizes, paint brushes and wooden sticks. The bodies were then documented with close-up photographs and a code was assigned; the tomb was marked with an identification arrow on the north end and the depth of the find was recorded with a grid or frame mapping. Afterwards, the

Table II. Field assessment data for each cemetery.

\begin{tabular}{|c|c|c|c|c|c|c|}
\hline Cemetery & Area (m2) & $\begin{array}{c}\text { Number of Probes } \\
\text { with Penetromer }\end{array}$ & $\begin{array}{c}\text { Compaction in } \\
\text { Newtons }\end{array}$ & $\begin{array}{c}\text { Number of } \\
\text { Pits }\end{array}$ & $\begin{array}{c}\text { Number of } \\
\text { Channels }\end{array}$ & Probes \\
\hline Orobajo & 1316 & 1200 & 200 a 400 & 275 & 175 & 1650 \\
\hline Barbacoas & 642 & 614 & 200 a 220 & 248 & 70 & 930 \\
\hline Fortuna & 330 & 260 & 100 a 300 & 40 & 3 & 303 \\
\hline Total & 2288 & 2074 & & 563 & 248 & 2883 \\
\hline
\end{tabular}


data about the exhumed skeletonized bodies were recorded in a spreadsheet: Information included the tomb, the grave goods, associated artifacts and isolated bone material. Finally, the ossified remains were removed and packed for relocation. Biologically immature individuals like fetuses or infants were exhumed in blocks of soil with the coffin included to provide greater protection during the transfer to the laboratory.

\section{Laboratory}

In the laboratory, photos were taken as each body was removed from its transportation packaging. To avoid confusing the bone pieces, each skeleton was unpacked on a separate table. As the fetuses and infants were exhumed in blocks, a micro-excavation was carried out to remove the ground deposit from the coffin once in the laboratory. A single block could contain two or more individuals. Next, soil was cleaned from the bones in a dry process, and roots and clothing were removed. The bones were then cleaned with water and soft-bristle brushes or paintbrushes to finish removing the foreign material. All the items in the funeral trousseau that accompanied the skeletons were similarly cleaned. Afterwards, the human remains and associated materials were dried at room temperature in shadow to prevent their deterioration. Next, each bone found in the exhumation was labeled with ink. Finally, skeletons were laid out anatomically on the tables for photographic documentation (See Figure 4).

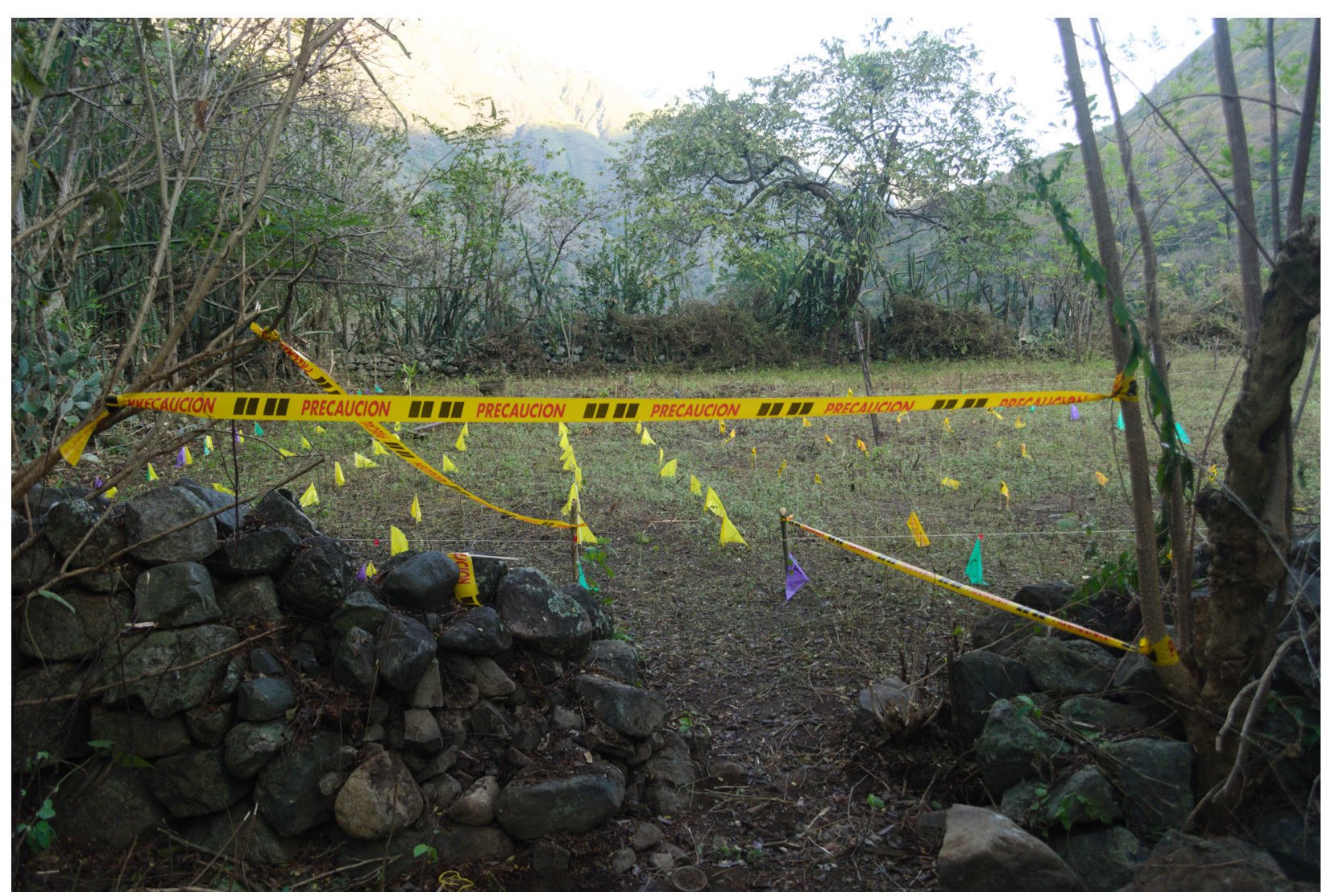

Figure 2. Photographs of the Barbacoas Cemetery with Flags Indicating Field Assessment Methods. Source: Image from the project, Field Assessment Phase. 


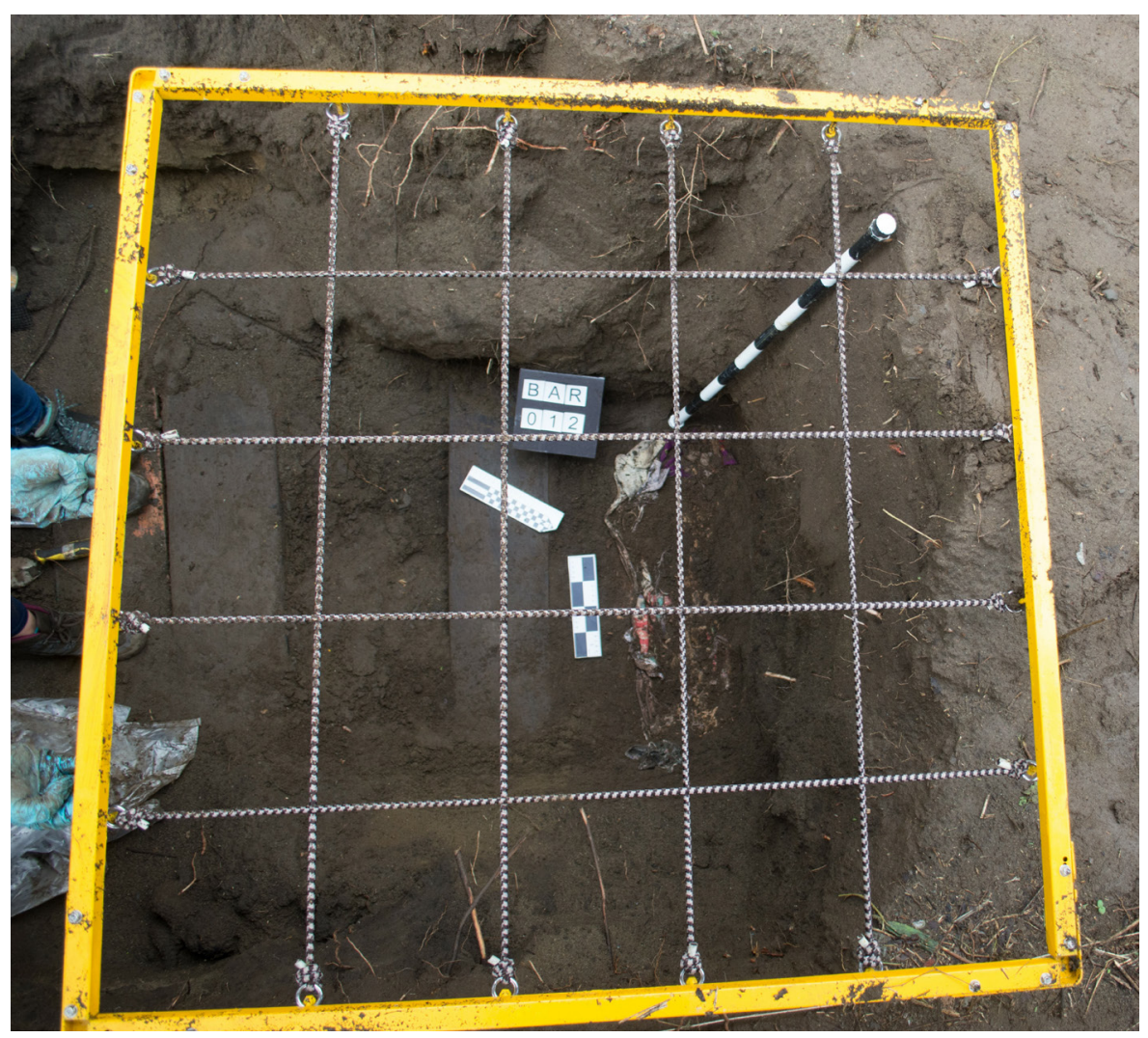

Figure 3. Photograph of the documentation model used for a tomb. Source: Image from the project, Field Assessment Phase Methods.

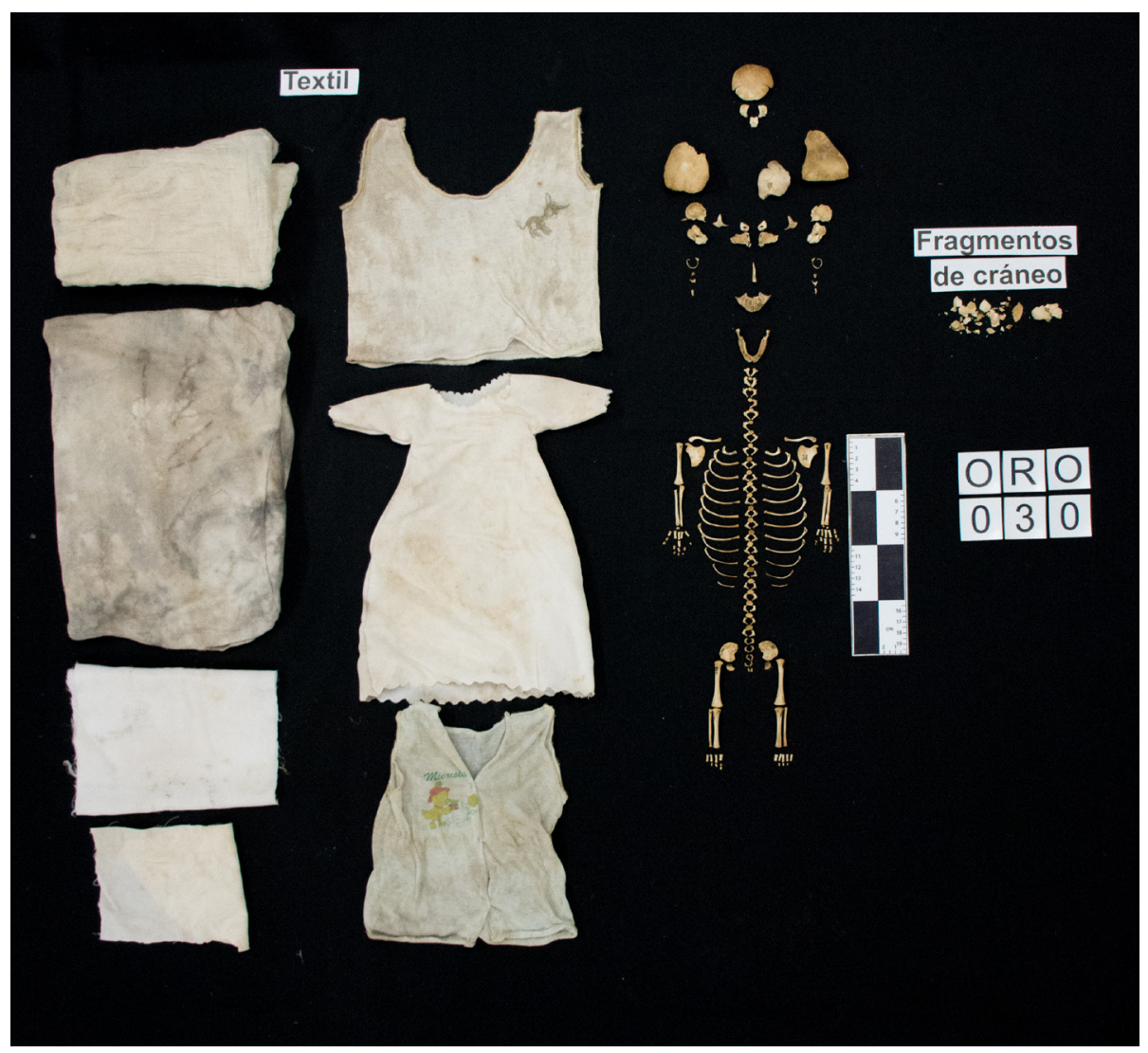

Figure 4. Photograph of the anatomical positioning of each bone in the skeleton of a biologically immature individual. 


\section{Identification}

In accordance with the types of bones and the level of deterioration in the materials, macroscopic and morphological techniques were chosen to identify sex and age at death. In mature skeletons, sex was determined in accordance to Buikstra \& Ubelaker (1994). When the skeleton was complete, the morphology of the pelvis was the first element analyzed, and the skull was second. Phenices (1969) method used when one or both of the coxals were present. In immature and sub-adult individuals, the Schutkowski (1993) identification method was used, relying on jaw and coxal to determine sex. The degree of fusion of the epiphysis in long bones, the appearance of different centers of ossification and the loss of baby teeth and their replacement by adult teeth was used to establish the age of the ossified remains at death in immature individuals. The age at death of sub-adult individuals over 17-years old and of adults was assessed using the Lovejoy et al. (1985) method, where the observed bone characteristics included the morphological changes in the atrial face of the ilium for evaluation of maturation in sub-adults and wear in adults. If the coxal had no atrial veneer, morphological changes of wear were observed in the articular facet of the pubic symphysis, as indicated by Todd (1920). For imature individuals, before the young adult stage, the Schaefer et al. (2009) maturation standard was used. These data were then categorized according to the age ranges proposed in Buikstra \& Ubelaker (1994), Baker et al. (2005) and Schaefer et al. (2009) (see Table IV). Finally, the undetermined category was established for the ossified remains for which it was not possible to establish age and sex due to taphonomic damage, wounds, severe wear, or in the cases where the ossified remains did not correspond with the chronological age reported by the relative and the biological age found with anthropologic methods.

Clothing elements and personal effects of the skeletonized body were used as a last recourse in the process of identification. Consequently, the ossified remains without identification were shown to the communities before the symbolic ceremonies of new burial so that they could be identified by their relatives through clothing or cultural elements.

\section{New burial}

The final disposition of the skeletonized bodies consisted in, first, symbolic activities guided by a psychologist expert in grief. Then, a human identification of the ossified remains, and finally with the respective religious ceremonies in the local churches.

Table III. Locations of ossified remains (data collected through pedological techniques).

\begin{tabular}{|c|c|c|c|c|c|c|}
\hline \multirow{4}{*}{ Cemetery } & \multicolumn{4}{|c|}{ Field prospecting phase } & \multirow{4}{*}{$\begin{array}{l}\text { Total body count } \\
\text { uncovered at site }\end{array}$} & \multirow{4}{*}{$\begin{array}{l}\text { Expected body } \\
\text { count }\end{array}$} \\
\hline & \multicolumn{4}{|c|}{ Techniques } & & \\
\hline & \multicolumn{2}{|c|}{ Pits } & \multicolumn{2}{|c|}{ Channels } & & \\
\hline & Total & Positives & Total & Positives & & \\
\hline Orobajo & 275 & 42 & 175 & 41 & 135 & 100 \\
\hline Barbacoas & 246 & 36 & 40 & 23 & 148 & 100 \\
\hline Fortuna & 40 & 10 & 3 & 2 & 18 & 10 \\
\hline Total & 560 & 88 & 218 & 66 & 301 & 210 \\
\hline
\end{tabular}


Table IV. Age at Death categorization (categories established according to anthropologic methods and biological maturation data from Buikstra \& Ubelaker (1994), Baker et al. (2005) and Schaefer et al. (2009)).

\begin{tabular}{|c|c|}
\hline Category & Age Range in Years \\
\hline Undetermined & None \\
\hline Pre-natal & $0-$ Birth \\
\hline Infancy & Birth - 1 \\
\hline Toddler & $1-3$ \\
\hline Final Stage Early Childhood & $3-6$ \\
\hline Childhood & $6-10$ \\
\hline Pre-pubescent & $10-12$ \\
\hline Pubescent & $12-15$ \\
\hline Older Adolescence & $15-20$ \\
\hline Young Adult & $20-35$ \\
\hline Middle Age & $35-50$ \\
\hline Senior Years & $>50$ \\
\hline
\end{tabular}

\section{RESULTS}

The data are here described in accordance with each phase carried out in the project. In the cemetery at Orobajo, the bodies consisted of people who had lived in the locality, and in some cases, on the slopes of Aurora, Nohavá y Remartin in the municipality of Sabanalarga. In the cemetery of Barbacoas, people from the slopes of San Julián de Barbacoas, Loma El Sauce, El Agrio, Nueva Llanada, Renegado Valle, Los Naipes and the sector of Boquerón were buried, as well as people from the center. Lastly, the cemetery at La Fortuna was used as a burial site until the violence of the 1950s, when the sector was abandoned. The current-day cemetery is smaller than the original because a large part of the north side was demolished by backhoes in mining activity on the terraces of the Cauca River. The founding dates of the cemeteries are unknown by local community members, although in Barbacoas, town elders consider that the cemetery site could have been a place of human burial for more than 80 years and in Orobajo, they estimate that the cemetery is approximately 40 years old. The tombs were distributed throughout the cemeteries (see Figures 5a, 5b and 5c). Nonetheless, as was discovered in the georeferencing, Orobajo and Barbacoas were more densely occupied than La Fortuna, especially in the zones closes to the entrances. In Orobajo, children and infants were often buried closer to the entrances, in contrast with the cemetery at La Fortuna (most used during the 1940s) were tombs and related funeral goods closer to the center of the space.

Approximately $62 \%$ of the tombs were at a depth between 100 and 150 centimeters. Specifically, 35.4\% were at a depth between 50 and 99 centimeters. Of the three cemeteries, Orobajo presented the largest quantity of tombs with the least depth, where $22.1 \%$ of the bodies found were buried at a depth somewhere between 0 and 100 centimeters. The form of the tombs varied between the three localities. In Orobajo, although there was no regular pattern, graves with side chamber wells were found, where wooden coffins were buried. Coffins were not covered with dirt because the community holds that it is bad luck and the deceased's soul cannot rest in peace if it is trapped. In Barbacoas and La Fortuna, the tombs were similar to modern graves in terms of the shape of the pit. In these burial sites, a pile of rocks was placed either on top of or under the coffin. Only in a few graves were wooden crosses or lily plants found, but the majority did not have these identifying elements on the surface of the grave.

Sometimes, the excavation uncovered pieces of a single skeleton at different ground levels or scattered in an area with a perimeter of one to two meters. The scattered pieces 

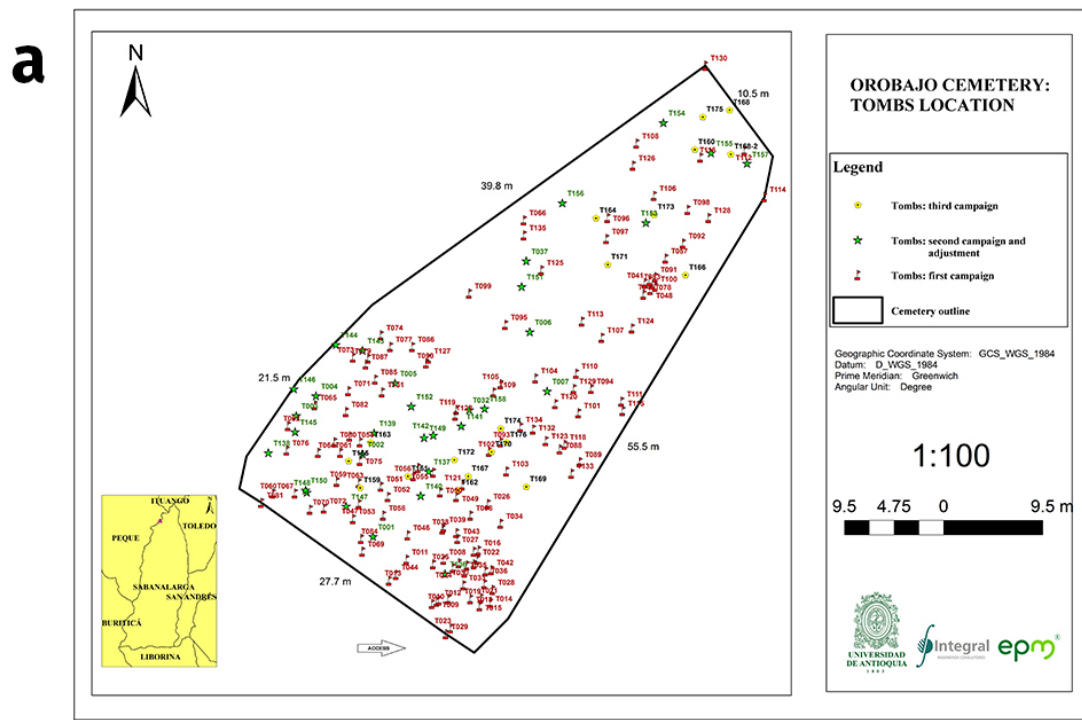

Figure 5. Maps of the distribution and georeferencing of the tombs in the cemeteries and the corresponding scale. a) Orobajo, b) Barbacoas and c) La Fortuna.
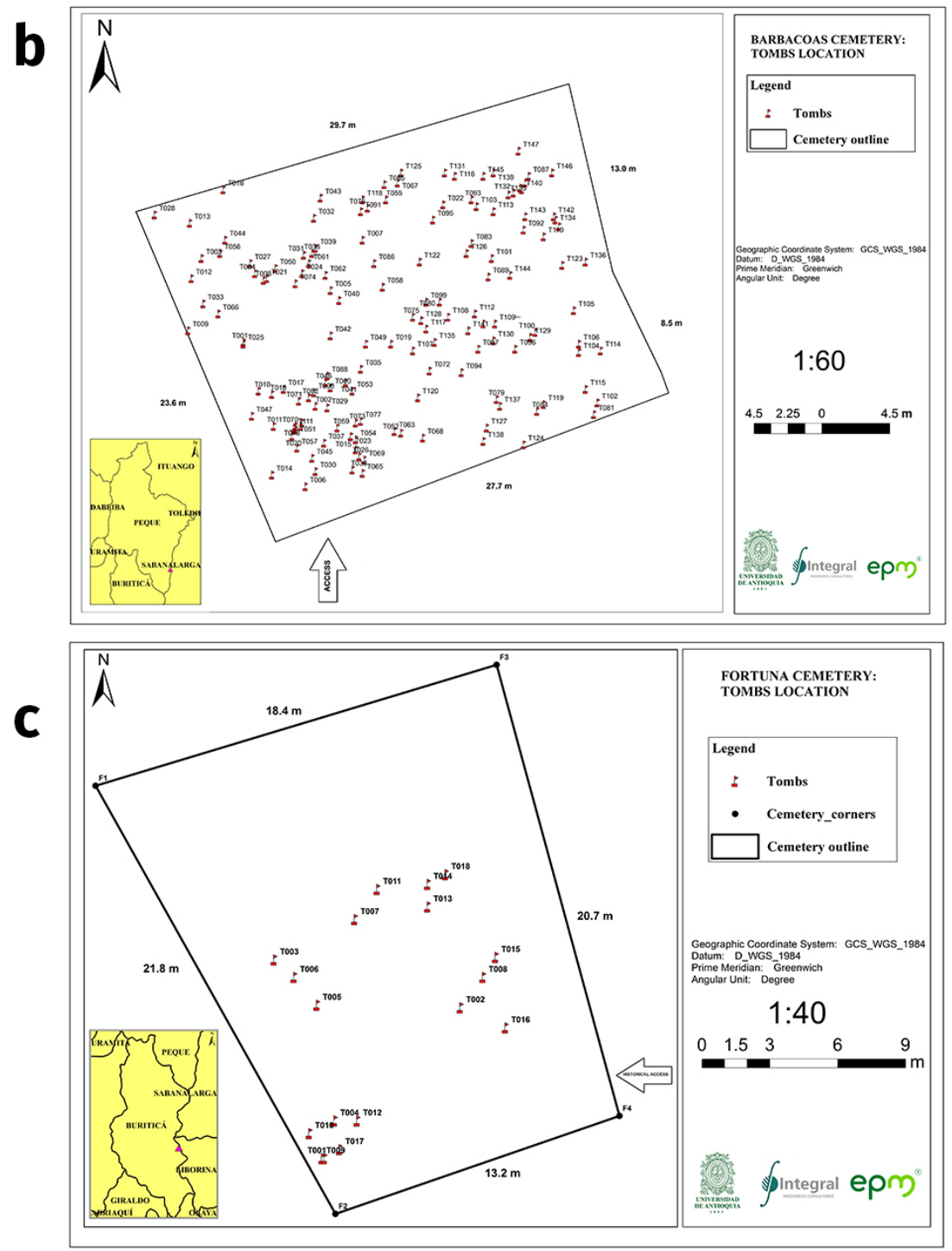
were recompiled according to anatomical characteristics, coloration or bone wear. Likewise, next to a complete skeletonized body, ossified remains of another individual were sometimes found dispersed throughout the tomb. However, these pieces were not associated with the complete skeleton which had been buried on top. Although the methods of burial were the same for children and adults were similar in the three localities, some differences were found. In Barbacoas, some of the dead were buried with a kerchief, or a scarf that covered the head to avoid the dislocation of the jaw when the cadaver begins decomposition. Many of the ossified remains were dressed in white clothing, especially infants and children, who were buried in Baptism dresses or tunics, white woolen socks, and crocheted white hats and mittens. Cups made of aluminum or paper were placed in their hands. Coffins were decorated with artificial flowers, and the children were buried with monkeys made from the shiny paper found in cigarette boxes, plastic animal figurines or other similar items. The bodies were covered in blankets, sheets or clothing, and pillows made from rags, blankets or clothing were placed under the body.

Adult women were generally buried in dresses or skirts of various colors and designs that reached their knees, as well as petticoats, underwear, and socks. According to the communities, the bodies were dressed in their "Sunday Best". Men were dressed in long, dark pants, button down shirts, either white or pastel colors, underwear and socks. In general, the deceased were buried with blankets, sheets, patchwork quilts and pillows made from blankets, rags, and clothing on which the bodies were rested. Some of the bodies were buried with scapulars or metal crucifixes in wooden coffins, usually made by the same community. Most of the bodies were laid out in accordance with the geographic orientation of the Cauca River, the mountains and their origin place of the deceased. Thusly, the majority of people from Barbacoas were buried in an east-west sense, while in Orobajo, they were buried in a southwest-northeast sense and in La Fortuna, and they were laid out in a north-south orientation. In all three locations, the orientation of the bodies coincided with the head facing the mountains and the feet directed towards the Cauca River. In some cases, the person was buried with their head towards the mountains, but facing the place where they came from, that is to say, the slopes near Orobajo or Barbacoas if appropriate. Similarly, most individuals were placed face up in a dorsal recumbent position. Only very infrequently were individuals found laid on their sides, either in fetal position or extended. In total, 349 skeletonized bodies were recovered (see Table V). From these, 301 skeletons were located using soil science techniques. An additional 32 individuals were uncovered during excavation, found in tombs that were not identified in the information provided by the communities, or scattered around the bodies of others. Finally, during the

Table V. Data of the skeletons located in each phase.

\begin{tabular}{|c|c|c|c|c|}
\hline & Field Assessment & Excavation & Laboratory & Total \\
\hline Orobajo & 135 & 32 & 13 & 180 \\
\hline Barbacoas & 148 & 0 & 3 & 151 \\
\hline Fortuna & 18 & 0 & 0 & 18 \\
\hline Total & 301 & 32 & 16 & $\mathbf{3 4 9}$ \\
\hline
\end{tabular}


cleaning and anatomic recompilation phases in the laboratory, an additional 16 skeletons were identified.

The bones showed evidence of taphonomic damage, both in cortical and spongy tissue. In many instances, roots from wild trees or flora planted by the community had grown into the bones. In other cases, the sand and rocks used to line and cover the surface of the tombs rubbed against the bones causing additional wear. Lastly, bones were damaged by the pressure from tomb stones or markers, placed on top of the buried bodies. In total, of the 349 individuals recovered from the different phases of the project, age could not be established for $40.7 \%$ because of the taphonomic damage described. Nonetheless, for the remaining percentage of the exhumed bodies, basic demographics could be established (See Table VI). The demographics from the exhumation show that the largest percentage of the exhumed skeletonized bodies, approximately one-third or $32 \%$, of the recovered bodies were in early stages of the life cycle, infancy and toddler (see Table VII). There is not much difference between Orobajo with $17.4 \%$ and Barbacoas with $13.7 \%$.

For $51 \%$ of the skeletonized bodies, sex was undeterminable; $27 \%$ of the ossified remains were identified as female and $22 \%$ as male. Analyzing the information by locality shows that, in Orobajo like in Barbacoas, a higher percentage of the bodies exhumed were female, 34\% and $21 \%$ respectively. Only in La Fortuna, was the percentage of the exhumations more male than female (26.3\% to $10.5 \%)$.

Table VI. Consolidated sex and age at death data of bodies exhumed in cemeteries.

\begin{tabular}{|c|c|c|c|c|c|c|c|c|c|}
\hline & & & & & ge at $\mathrm{De}$ & & & & \\
\hline & & & Undetermined & Fetus & Infant & Child & Youth & Adult & Total \\
\hline & & Undetermined & 38 & 6 & 12 & 6 & 2 & 11 & 75 \\
\hline & Sex & Male & 16 & 0 & 8 & 12 & 0 & 8 & 44 \\
\hline & & Female & 10 & 6 & 21 & 12 & 4 & 8 & 61 \\
\hline & & Total & 64 & 12 & 41 & 30 & 6 & 27 & 180 \\
\hline & & Undetermined & 60 & 1 & 17 & 8 & 3 & 2 & 91 \\
\hline & Sex & Male & 5 & 0 & 2 & 6 & 2 & 13 & 28 \\
\hline Dar acuas & & Female & 2 & 1 & 10 & 6 & 2 & 10 & 31 \\
\hline & & otal & 67 & 2 & 29 & 20 & 7 & 25 & 150 \\
\hline & & Undetermined & 8 & 0 & 2 & 1 & 0 & 1 & 12 \\
\hline & Sex & Male & 3 & 0 & 0 & 1 & 1 & 0 & 5 \\
\hline (vicuia & & Female & 0 & 0 & 0 & 1 & 0 & 1 & 2 \\
\hline & & otal & 11 & 0 & 2 & 3 & 1 & 1 & 19 \\
\hline & & Undetermined & 106 & 7 & 31 & 15 & 5 & 14 & 178 \\
\hline & Sex & Male & 24 & 0 & 10 & 19 & 3 & 21 & 77 \\
\hline & & Female & 12 & 7 & 31 & 19 & 6 & 19 & 94 \\
\hline & & otal & 142 & 14 & 72 & 53 & 14 & 54 & 349 \\
\hline
\end{tabular}


Table VII. Consolidated information about age at death.

\begin{tabular}{|c|c|c|c|}
\hline Estimated Age & Frequency & Percentage & Accumulated Percentage \\
\hline Undetermined & 142 & 40.7 & 40.7 \\
\hline Prenatal & 14 & 4 & 44.7 \\
\hline Infancy & 72 & 20.6 & 65.3 \\
\hline Toddler & 40 & 11.5 & 76.8 \\
\hline Final Stage Early Childhood & 8 & 2.3 & 79.1 \\
\hline Childhood & 5 & 1.4 & 80.5 \\
\hline Older adolescence & 6 & 1.7 & 82.2 \\
\hline Young adult & 8 & 2.3 & 84.5 \\
\hline Middle Age & 16 & 4.6 & 89.1 \\
\hline Senior Years & 38 & 10.9 & 100 \\
\hline Total & 349 & 100 & \\
\hline
\end{tabular}

\section{DISCUSSION}

Establishing the sex and the age at death of the exhumed individuals was the most problematic aspect of the work because of complex multifaceted issues: a) burial practices like burying one person on top of another or digging up old graves to deposit new bodies; b) the long-time use or old age of the cemetery without written or oral records to establish correspondences between buried individuals and the exhumed bodies; c) bodies buried by the community without clothing or personal artifacts that allow anthropologists to establish some facts based on related elements; d) the scarcity of antemortem or ethnographic data during the pre-fieldwork phases due to the populations' lack of information in relation to their cemeteries; e) the evident taphonomic damage of the skeletonized bodies and individual bones due to the interaction with the surrounding environment. Age at death of the exhumed individuals was therefore determined through analyses of the maturation processes in human bones in accordance with existent international methodologies that, although they have not been tested on Colombian populations, give data about the biological age at death. Another problematic element in the anthropology was the identification of sex in biologically immature individuals through morphometrics because the sexual characteristics expressed in bone appear after maturation. In relation to the anterior, Schutkowski (1993) developed the means of establishing sexual dimorphism based on probable traits in immature skeletons found in in old cemeteries containing a considerable number of infants or young children. The project used these methods to identify sex in immature skeletons, even though the same size was small with insufficient external validation due to the lack of replicability in other Colombian populations.

A third of the skeletonized bodies were in early life cycle stages corresponding to infancy and early childhood. Bones of young children are not yet fully developed; they still have a large quantity of collagen, which means that the bones are fragile in terms of the hardness of the material and are little resistant to deterioration in interaction with the ground. Likewise, immature bones are more susceptible to mineralization in the surrounding environment where they are deposited. The fragility of this material opens 
complex questions for scientific investigation like type of bones, quantity of organic and inorganic material, ground conditions and degradation processes in burial sites and research based on bone diagenesis. Yet, even though this ossified matter is more fragile, it was the largest quantity recuperated. The fact that the largest percentage of the bodies buried at the three cemeteries were infants and toddlers sheds light on the importance of social development and its effects on mortality rates in vulnerable populations and impoverished areas. As the World Health Organization argues (OMS 1995, Beaton et al. 1990), poverty, living in deteriorated environments, poor diet and behavioral patterns associated with living in these conditions have large impacts on health risks and high mortality rates in the first stages of the life cycle. For that reason, life expectancy in children ages 0 and 5 years is an important factor in establishing indices of social development and risk in populations. Poverty and the direct correlation it has with multiple dimensions like individual health, development, and socioeconomic and environmental conditions (Beaton et al. 1990, OMS 1995) are highlighted in our findings. Despite the difficulties, the identification phase was the most interesting, not only due to the small number of cases worldwide, but also because it showed the scientific need to articulate knowledge about bone maturation and sexual dimorphism in populations which also show signs of malnutrition in the ossified remains. This last is important because, over the past 40 years scientists have shown a relationship between malnutrition and bone maturation (Himes 1978, Alvear et al. 1986, Linhares et al. 1986, Mays et al. 2009). Biological methodologies combined with ethnographic techniques permitted the establishment of more precise age ranges and the probable identification for 30 individuals in Orobajo and Barbacoas.

\section{CONCLUSION}

Initial estimates, calculated in accordance with the information supplied by local communities, predicted a total of 210 bodies in the cemeteries at Orobajo, Barbacoas, and La Fortuna. Nonetheless, when the project combined edaphological soil science techniques with anthropological techniques from bioanthropology and archaeology, $166.2 \%$ of the expected number of bodies were found, exhumed and recovered for their relocation to new sites. The findings show the importance of an interdisciplinary approach, which is more efficient and returns more knowledge than any one discipline by itself. The work of anthropologists and edaphologists complements forensic and bioanthropological research conducted at irregular cemeteries in relation to the types of deposits and the forms of burials among others, for a more complete understanding of the field. A total of 349 bodies were exhumed from three cemeteries on the terraces of the Cauca River in the direct area of influence of the Ituango Hydroelectric Project. The cemeteries were characterized as irregular due to the burial practices for which there is a lack of forensic or archeological context. Forensic, anthropological, bioanthropological and soil science methods were used in combination to identify sex and age at death for the remains. Results showed high infant and early childhood mortality rates as well as signs of chronic malnutrition in the bones. These findings demonstrate that the exhumation of cemeteries not only has symbolic value in territorial appropriation by relocated communities but can also provide relevant demographic and social information for retrospective research about the relationship between deteriorated environments and public health. 


\section{Acknowledgments}

The cemetery relocation project was carried out by the Universidad de Antioquia and the company INTEGRAL S.A. under the contract CT-2017-001472 EXHUMACIÓN DE CUERPOS. We recognize Professor Juan Carlos Loaiza, anthropologist, logistic engineer and photographer at the Universidad Nacional de Colombia, for his work on the edaphological elements of the project, as well as the students in the Environmental Engineering program and the masters in Environment and Development and the Universidad Nacional de Colombia with Project Code: 43009 and Code QUIPU: 201010022322 project INVESTIGACIÓN GEO-OSTEOLÓGICA EN CONTEXTOS DE CEMENTERIOS. Most especially, we thank the communities of Orobajo, Barbacoas and Buriticá that supported and participated in the project in its different phases. Finally, thanks to Tatiana Alvarez for her support of the project.

\section{REFERENCES}

ALVEAR J, ARTAZA C, GUeRrero S \& MuZzo S. 1986. Physical growth and bone age of survivors of protein energy malnutrition. Arch Dis Child 61(3): 257-262.

BAKER BJ, DUPRAS TL \& TOCHERI MW. 2005. The Osteology of Infants and Children. Texas A\&M University press, 178 p.

BANKS K \& CZAPLICKI J. 2014. Dam projects and the growth of American archaeology: the river basin surveys and the interagency archeological salvage program. California, Left Coast Press, Inc, 318 p.

BEATON G, KELLY A, KEVANY J, MARTORELL R \& MASON J. 1990. Appropriate Uses of Anthropometric Indices in Children. Nutrition policy discussion paper No. 7, 672 p.

BUIKSTRA J \& UBELAKER DH. 1994. Standards for data collection from human skeletal remains. Arkansas Archaeological Survey Research.

ELLIS M. 1996. Bull Shoals Lake and Cemetery. OzarksWatch (Series 1, Vol. 9, No. 3): Bull Shoals, p. 3-5.

EPM - Empresas Públicas de Medellín. 2013. Comunidad y medio ambiente. Retrieved from https://www. epm.com.co/site/comunidadymedioambiente/ comunidad-y-medio-ambiente / comunidad / gestion-social-de-impactos.

ESPINAL T. 1992. Geografía ecológica de Antioquia: Zonas de vida. Universidad Nacional de Colombia, Facultad de Ciencias y Facultad de Ciencias Agropecuarias, 106 p.
GENNEP AV. 1986. Los ritos de paso. Alianza Editorial. Madrid, $312 \mathrm{p}$.

HARRIS JE, PONITZ PV \& SAMIR LOUTFY M. 1970. OrthodonticS 'contribution to UNESCO's campaign to save the monuments of Nubia:A 1970 field report. Am J Orthod 58(6): 578-596. https://doi.org/10.1016/0002-9416(70)90146-6.

HARVEY T. 2006. Sacred spaces, common places: The cemetery in the contemporary American city. Geogr Rev 96(2): 295-312.

HIGGINS JF. 2013. Deathscapes: designing contemporary landscapes to solve modern issues in cemeteries. (Master's thesis) Texas Tech University, Athens, Georgia, 174 p. (Unpublished).

HIMES JH. 1978. Bone growth and development in proteincalorie malnutrition. In Some Aspects of Human and Veterinary Nutrition. Karger Publishers, p. 143-187.

JUDD M. 2004. News from the British Museum. UK.

LINHARES ED, ROUND JM \& JONES DA. 1986. Growth, bone maturation, and biochemical changes in Brazilian children from two different socioeconomic groups. Am J Clin Nutr Oct 44(4): 552-558. doi: 10.1093/ajcn/44.4.552. PMID: 3766438.

LOVEJOY CO, MEINDL RS, PRYZBECK TR \& MENSFORTH RP. 1985. Chronological metamorphosis of the auricular surface of the ilium: a new method for the determination of adult skeletal age at death. Am J Phys Anthropol 68(1): 15-28.

MAYS S, IVES R \& BRICKLEY M. 2009. The Effects of Socioeconomic Status on Endochondral and Appositional Bone Growth, and Acquisition of Cortical Bone in Children From 19th Century Birmingham, England. Am J Phys Anthropol 140(December 2008): 410-416. https:// doi.org/10.1002/ajpa.21076.

MEDICINA LEGAL. 2004. Resolución No. 001036. Instructivo para la documentación fotográfica digital en la investigación de delitos sexuales y lesiones personales, Bogotá, Colombia, 82 p.

MEDICINA LEGAL. 2017. Estándares forenses mínimos para la búsqueda de personas desaparecidas, y la recuperación e identificación de cadáveres, Bogotá, Colombia, $92 \mathrm{p}$.

MINISTERIO DE LA PROTECCIÓN SOCIAL. 2010. Resolución No. 5194. Prestación de los servicios de cementerios, inhumación, exhumación y cremación de cadáveres. Pub L No 47.925 (2010), Colombia, Ministerio de la Protección Social. 
OMS 1995. El estado físico: uso e interpretación de la antropometría, Geneva, Switzerland.

PATTISON WD. 1955. The cemeteries of chicago: a phase of land utilization. Ann Assoc Am Geogr 45(3): 245-253. https://doi.org/10.1111/j.1467-8306.1955.tb01672.x.

PHENICE TW. 1969. A newly developed visual method of sexing the os pubis. Am J Phys Anthropol 30(2): 297-301.

SCHAEFER M, BLACK SM \& SCHEUER L. 2009. Juvenile osteology. London, Academic Press, Inc, 384 p.

SCHUTKOWSKI H. 1993. Sex determination of infant and juvenile skeletons: I. Morphognostic features. Am J Phys Anthropol 9(2): 199-205.

THE MINNESOTA PROTOCOL ON THE INVESTIGATION OF POTENTIALLY UNLAWFUL DEATH. 2016. Office of the United Nations High Commissioner for Human Rights, New York/Geneva, 2017.

THIEL JH \& MARGOLIS MM. 2007. Excavation and Analysis of Burials 13 and 14 from the Court Street Cemetery. AZ BB 13: 156 (ASM), Tucson, Pima County, Arizona, Tucson, 54 p.

TODD TW. 1920. Age changes in the pubic bone. I. The male white pubis. Am J Phys Anthropol 3(3): 285-334.

UBELAKER D. 1995. Historic cemetery analysis: Practical considerations. In: Wiley J \& Song S (Eds). Bodies Of Evidence: Reconstructing History Through Skeletal Analysis, New York, p. 37-48.

\section{How to cite}

VARGAS TM, URIBE CL, BEDOYA SV, ZAPATA MLQ \& CARDONA-GALLO SA. 2022. Cemetery Relocations in Hidroituango: An Interdisciplinary Study. An Acad Bras Cienc 94: e20201098. DOI 10.1590/0001-3765202220201098.

\section{Manuscript received on July 13, 2020;}

accepted for publication on August 18, 2020

\section{TIMISAY M. VARGAS}

https://orcid.org/0000-0002-8046-9006

\section{CECILIA L. URIBE ${ }^{1}$}

https://orcid.org/0000-0002-4690-0114

\section{SANTIAGO V. BEDOYA ${ }^{2}$}

https://orcid.org/0000-0001-6383-9856

\section{MARY LUZ Q. ZAPATA ${ }^{3}$}

https://orcid.org/0000-0001-5072-9439

\section{SANTIAGO A. CARDONA-GALLO}

https://orcid.org/0000-0002-1875-7330

${ }^{1}$ Universidad de Antioquia, Departamento de Antropología, Calle 67, 53-108, 05-0010, Ciudad Universitaria Medellín, Antioquia, Colombia

${ }^{2}$ Universidad Nacional de Colombia Sede Medellín, Departamento de Geociencias y Medio Ambiente, Facultad de Minas, Carrera 80, 65-223 (M2-319), 05-0034, Medellín, Antioquia, Colombia

${ }^{3}$ Empresas Públicas de Medellín, Carrera 58, 42125, 05-0012, Medellín, Antioquia, Colombia

Correspondence to: Santiago Alonso Cardona-Gallo E-mail:scardona@unal.edu.co

\section{Author contributions}

Conceptualization and experiment designs by Timisay Monsalve Vargas, Mary Luz Quiroz Zapata and Santiago Alonso CardonaGallo. Writing-review and editing were conducted by Timisay Monsalve Vargas and Santiago Alonso Cardona-Gallo. Cecilia Londoño Uribe, Santiago Vélez Bedoya and Timisay Monsalve Vargas performed the laboratory measurements and data processing.

\section{(cc) BY}

